\title{
アスファルト混合物の動的性状とその 舗装構造の力学解析への利用*
}

\author{
DYNAMIC PROPERTY OF BITUMINOUS MIXTURE AND ITS \\ APPLICATION TO ANALYSIS OF PAVEMENT STRUCTURE
}

\author{
笠 原篤**・岡 川秀 幸*** 菅 原 照 雄**** \\ By Atsushi KASAHARA, Hideyuki OKAGAWA and Teruo SUGAWARA
}

\section{1. 概 説}

アスファルト舗装の力学的な構造解析は弾性学の分野 でまた材料学的研究は粘弾性の分野でめざましい進展を とげている．これらの研究を互いに関連つけることによ りアスファルト舗装の合理的設計なる目的に一歩近づけ ることができよう。しかし現在の段階においては，ごく 一部を除いてそれらを関連ゔける研究はきわめて少な W.

アスファルト舗装構造の理 論解析は, 各層の変形係 数, ポアソン比などの数值ならびに境界条件など多くの 仮定に立脚していることから, 実際の道路の環境条件下 における舗装体のひずみおよび応力を正確に算出するこ とは非常に困難である.それは層を構成している材料の 力学的性状を十分には握することが著しく困難なこと実 際の環境条件を数量化することができていないことなど に起因している. 土質材料から構成される路床, 路盤に 関しては, 土質工学的なアプローチが必要であり, 理論 計算に必要な数值を得ることが重要であろう。この点に 関し, CBR と変形係数との関係について多くの研究が ある. そのうち Heuklom, W., Klomp, A.J.G. ら ${ }^{1)}$ が行った弾性波の伝播速度による研究は層としての変形 係数という観点から注目されるものの1つである.これ らに関連したものとしてダイナフレクト，ロードレイタ (いずれも米国における商品名) などを利用した舗装構 造の評価に関する研究も活発に行われている.

アスファルト混合物をもって構成される層（以下これ を単にアスファルト層とよぶ）については, それの力学 的性状㯰境条件すなわち温度ならびに載荷時間に大き

* 土木学会符 30 回年次学術講演会 V-139 にて一部発表

** 正会員 工博 北海道大学助手 工学部土木教室

*** 正会員 工修 大成建設(株) 土木設計部

**** 正会員 工博 北海道大学教授 工学部土木教室
く支配され，特にアスファルト層の変形係数は，それが 粘弾性体であることから，温度と載荷時間の関数として 示される．換言すれば理論計算に用いるべき変形倸数は 温度ならびに載荷時間を無視して決定することはできな W.

舗装体の温度分布に関しても多くの研究があり，その 分布は外気温，日射，風など多くの因子に影響されるこ とが知られている.しかしアスファルト層の盜度分布に ついては，ごく狭い温度領域ごとにアスファルト層を分 割し, 各温度の $n$ 層の積重ねからアスファルト層が構成 されていると考えることにより取扱うことも可能とな る.

一方舗装体における載荷時間に関しては, 車両走行速 度により一義的に決定されると考えられるが，層が荷重 分散性能を具備していることから, 層の深さによって載 荷時間が異なる.すなわち深部ほど大となることは容易 に推測される.この点に関し, 理論計算, 実測などによ り, 2,3 の研究者による研究があるが, アスファルト層 の動的性状との関連性という観点からはいまだほとんど 論議されるに至ってはいない.

以上の観点から, 本研究においてはアスファルト混合 物の動的性状を求め, 層構造の榣性理論解法において重 要な入力データである “層の変形係数”を合理的に決定 するための“層における載荷時間の取扱い”について検 討し，かつアスファルト混合物の疲労性状をも检討し， アスファルト混合物の動的性状と層構造理論との結びつ きを検討した．なお舗装体の温度については，本研究に おいては代表的温度においてのみ論を進めているが，ア スファルト混合物の弾性率に関してはマスターカーブ群 を描くことにより他の多くの温度への適用を可能にして いる.

道路舗装材料としてのアスファルト混合物の動的性状 を求めるための手法としては，筆者らの既発表論文 ${ }^{2)}$ おいて述べたように粘弾性学の分野で広く利用されてい 
る強制振動非共振法, 共振法などがあり，その振動は正 弦波であることから，載荷時間は $1 / \omega(\omega$ : 角速度) で 定義される. しかしアスファルト混合物の動的性状を道 路舗装構造に反映させる場合の問題点は走行車両による 載荷時間が明らかでないことにある。筆者らが注目した のは走行車両によってアスファルト層下面纪生ずる半径 方向のひずみ分布であり，その波形は理論計算および実 測などにより Bell Shape Wave であることが明ら かになっている3). 本実験研究においては Bell Shape Wave を, ピンボードシステムを持つ動的載荷装置によ り,アスファルト混合物の供試体に生ぜしめ(以下この波 形をプログラム波とよぶ）その応答を求める一方，正弦 的に変化するひずみ波形を入力とする強制振動非共振法 により動的応答を求め, その両者の波形による応答の差 を明らかにし，弾性係数を同一にする載荷時間を求め， 層構造における載荷時間を規定することを試みた。

またアスファルト混合物が繰り返し載荷を受ける場 合, アスファルト混合物の動的性状は変化することは筆

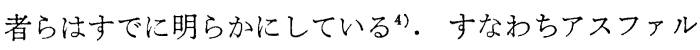
卜混合物の複素弹性率は繰り返し載荷回数が増大すると 低下し, 初期の值の 5 15\% 程度低下寸れば疲労破壊 をおこしはじめる．換言するならば疲労破壊をおこしは じめるまでは, アスファルト混合物は初期の弾性率の 95 85\% の值を維持しており，理論計算において用い るべき層の変形係数としていかなる值を採用するかは技 術的判断となるが，アスファルト層が荷重分散性能を確 保している期間が問題となる.このことから繰り返し載 荷過程における弾性率の変化を論ずるためにも以下に述 ベる疲労性状をも検討した。

アスファルト混合物の疲労性状は，与えたひずみまた は応力の大きさと破壞回数との関係で論じられ，通常そ のひずみまたは応力は正弦的に変化するものを用いてい る.しかし実際の道路舗装に生ずるひずみまたは応力は 先に述べたように正弦的に変化するものではないことか ら，実際の道路舗装に生ずる波形によるアスファルト混 合物の疲労性状を求めることが重要である.このことか ら本研究ではひずみ制御方式の繰り返し載荷試験におい て，正弦波㧍よびプログラム波を入力としたとき，アス ファルト混合物の疲労性状にいかなる差異があるかを検 討した.

なお本稿では,“種々のかたちでの応力とひずみの比” として表わされるものを, 正弦波で測定したとき複素弾 性率 (Complex Modulus), プログラム波で測定したと きスティフネス（Stiffness）とよび, 両者を一括して弾 性率 (Stiffness Modulus) とよぶ. また層を構成した 場合には，それを層の変形係数 (Stiffness of Asphalt
Layer）とよぶこととする.

\section{2. アスファルト層に生ずるひずみ}

アスファルト層, 路盤, 路床からなる 3 層構造につい て, 層構造の弾性理論解法を適用し, アスファルト層下 面に生ずる半径方向のひずみ $\left(\varepsilon_{r}\right)$ を算出することを試 みたこここで用いた層構造の弾性理論解法は Burmister, D.M. ${ }^{5)}$ の理論を基礎として Schiffman, R.L. ${ }^{6)}$ が $n$ 層 構造の一般解を与えたものを, 芳村ら ${ }^{7}$ がハンケル変換 などを用いて電子計算機に入力できるようにプログラム 化したものを用いた。ここで計算を行うにあたっての仮 定は以下の通りである.

a）載荷は等分布円荷重による.

b）各層は半径方向に半無限であり, 均質弾性体であ る.

c）第 2 層 (路盤に相当)および第 3 層 (路床に相当) の弾性係数に関しては在来の研究の結果 ${ }^{8)}$ から, 本 研究の範囲内では時間および温度依存性を無視して 差し支えないことが明らかであることから, 温度な らびに載荷時間依存性がないものとし, その大きさ は $110 \times \mathrm{CBR}^{9)}$ で与えられるものとする.

d）各層のポアソン比はすべて 0.5 であるとする.

e）各層間は完全汇粗（せん断力を伝達する）である とする.

また 3 層構造の弾性理論解法のインプットデータは

$a:$ タイヤの接地半径 $(\mathrm{cm})$

$P:$ タイヤの接地圧 $\left(\mathrm{kg} / \mathrm{cm}^{2}\right)$

$E_{i}:$ 各層の弾性係数 $\left(\mathrm{kg} / \mathrm{cm}^{2}\right)$

$H_{i}$ : 各層の厚さ $(\mathrm{cm})$

$\nu_{i}:$ 各層のポアソン比

などである. なお本研究においては, アスファルト混合 物の動的性状と舗装構造との関連を主眼としていること から計算の煩雑さをさけるため, 变数を $E_{1}$ とし, 他の 変数は以下のように固定した.

a) 輪荷重 $5 \mathrm{t}$ $a=17 \mathrm{~cm}, P=5.51 \mathrm{~kg} / \mathrm{cm}^{2}$

b) 各層の厚さ $H_{1}=20 \mathrm{~cm}, H_{2}=60 \mathrm{~cm}, H_{3}=\infty$

c) 路盤, 路床の $\mathrm{CBR}, 75$ および 5 $E_{2}=8250 \mathrm{~kg} / \mathrm{cm}^{2}, E_{3}=550 \mathrm{~kg} / \mathrm{cm}^{2}$

d) 各層のポアソン比 $\nu_{1}=0.5, \nu_{2}=0.5, \nu_{3}=0.5$

図一1には，図中に示した 3 層構造において， $E_{1}$ を $1.0 \times 10^{4} \sim 1.0 \times 10^{5}$ と変化させた場合の $\varepsilon_{r}$ の分布を算 出した結果を示した.

図より $E_{1}$ の低下にともないアスファルト層下面に生 


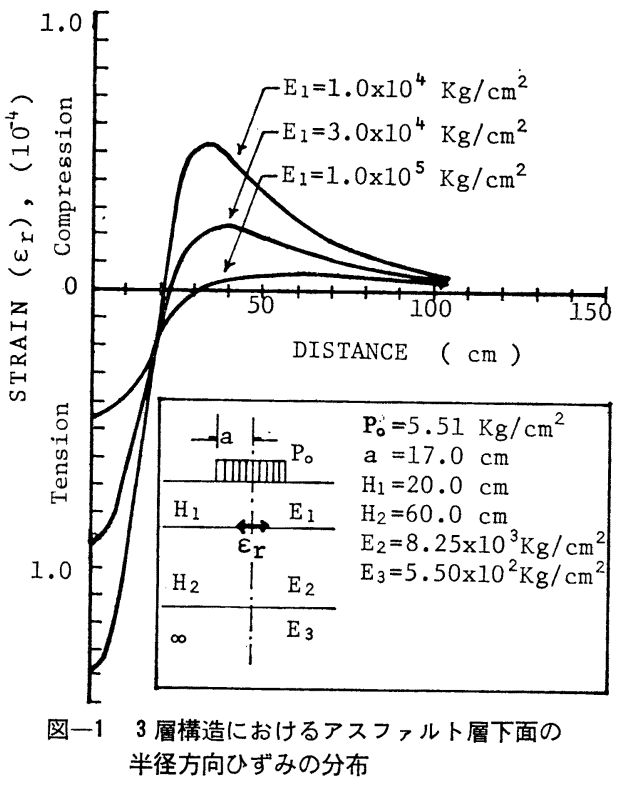

ずるひずみ $\left(\varepsilon_{r}\right)$ は増大し， $E_{1}$ が $1.0 \times 10^{5} \mathrm{~kg} / \mathrm{cm}^{2}$ か ら $1.0 \times 10^{4} \mathrm{~kg} / \mathrm{cm}^{2}$ に低下すると距離ゼロにおける $\varepsilon_{r}$ は $4.5 \times 10^{-5}$ から $1.4 \times 10^{-4}$ と約 3 倍にも増大するこ とを示している．このことを道路舗装㯰き換えて考え るとき， $E_{1}$ の低下は気温の上昇あるいは車両走行速度 の低下としてとらえることができ， $E_{1}$ が1オーダ小さ くなるとひずみは約 3 倍にも増大することは，アスファ ルト混合物の温度依存性, 疲労性状（後述）などを考え るとき，きわめて大きな意味をもつことになろう。

\section{3. 実験研究の方法および試料}

\section{（1）実験研究の方法}

a) 載荷装置

本研究に用いた载荷装置は舖装用材料の䜤試体に電気 ・油圧サーボ機構により，静的ならびに動的載荷および 繰り返し載荷試験を行うことのできる装置であり，これ は油圧部, 制御部, 載荷部, 記録部, 温度制御部から構 成されている. 各部の機能については，その詳細を既発 表論文 ${ }^{10)}$ に示しているので, ここでは任意波形（プログ ラム波）の発生機構に関連したもののみを述べる.

本装置の任意波発生機構はダイオードマトリックス方 式であり, 時間軸 60 穴, 電圧軸 16 穴の計 1860 穴を もつピンボード (写真一1) にダイオードピンを差込み， フィルタを通すことによりかなりスムースな形をした任 意波形を得ることができる. 60 穴の時間軸を掃查する 時間を $0.1 \sim 99.9$ 秒の範囲内で 0.1 秒単位で設定する ことができる．また本ピンボードシステムはインターバ

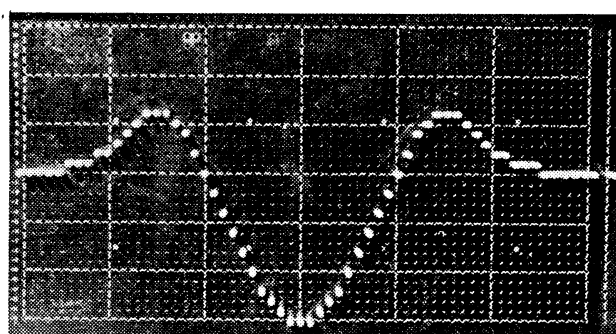

写真-1 ピンボード

ル軸（電圧軸 16 穴）をも併せもち，任意のレベルの電 圧をインターバル 時間設定機構により 1 99 秒の範囲 内で 1 秒単位で設定することができる.

b) 試 験 法

実験は動的載荷試験ならびに繰り返し載荷試験とも正 弦波およびプログラム波を入力とするひずみ制御方式で 行い，与えるひずみ量は線型粘弾性領域と考えてもよい $10^{-4}$ のオーダー，これは舗装体のアスファルト層下面に 実際に生ずるひずみ領域の上限近辺でもある值を用い た.

合成ゴムで被覆された供試体をスパン $30 \mathrm{~cm}$ ，載荷点 間隔 $10 \mathrm{~cm}$ にセットし, 温度管理された恒温水槽中に おいて動的載荷試験 ならびに繰り返し載荷試験を行っ た. 試験条件などは一括し 表一1 に示されている.

\section{表一1 試 験 条 件}

\begin{tabular}{lcccc}
\hline & Strain & $\begin{array}{c}\text { Tempe- Sweep } \\
\text { rature } \\
\left({ }^{\circ} \mathrm{C}\right)\end{array}$ & $\begin{array}{c}\text { Fre- } \\
\text { Time } \\
(\mathrm{sec})\end{array}$ & $\begin{array}{c}\text { Fuency } \\
(\mathrm{Hz})\end{array}$ \\
\hline $\begin{array}{l}\text { Dynamic Test } \\
\text { Programmed wave }\end{array}$ & $2.0 \times 10^{-4}$ & $-15 \sim 20$ & $0.2 \sim 50.0$ & - \\
$\begin{array}{l}\text { Sinusoidal wave } \\
\text { Fatigue Test }\end{array}$ & $2.0 \times 10^{-4}$ & $-15 \sim 20$ & - & $0.1 \sim 10.0$ \\
$\begin{array}{l}\text { Programmed wave } \\
\text { Sinusoidal wave }\end{array}$ & $(5.5 \sim 11.0) \times 10^{-4}$ & $-10 \sim 10$ & 0.1 & - \\
\hline
\end{tabular}

\section{（2）試料}

試験混合物としては一般舗装用加熱混合物の代表的な ものとして密粒度アスファルトコンクリートを採用し た.なお粒度組成ならびにバインダー性状は 表一2 に

表一2 粒度組成およびバインダー性状

\begin{tabular}{|c|c|c|}
\hline $\begin{array}{c}\text { Sieve } \\
\text { Opening } \\
(\mathrm{mm})\end{array}$ & $\begin{array}{c}\% \\
\text { Passing }\end{array}$ & Binder \\
\hline 13.0 & 100.0 & Straight Asphalt \\
\hline 10.0 & 93.0 & $80 / 100$ \\
\hline 7.0 & 77.0 & PEN. $\left(25^{\circ} \mathrm{C}, 100 \mathrm{~g}, 5 \mathrm{sec}\right): 83$ \\
\hline 5.0 & 70.0 & $\mathrm{~T}_{\mathrm{R} \& \mathrm{~B}}\left({ }^{\circ} \mathrm{C}\right) \quad: 48.0$ \\
\hline 2.5 & 50.0 & $:-0.4$ \\
\hline 1.2 & 40.0 & \\
\hline 0.6 & 30.0 & \\
\hline 0.3 & 19.9 & \\
\hline 0.15 & 9.1 & \\
\hline 0.074 & 5.6 & \\
\hline
\end{tabular}


示した通りであり，混合物中のバインダー量は $5.55 \%$ である。

各材料を 2 ポアズ温度 $\left(149^{\circ} \mathrm{C}\right)$ で加熱混合し, $40 \times$ $30 \times 6 \mathrm{~cm}$ の鋼製型枠内で 30 ポアズ温度 $\left(102^{\circ} \mathrm{C}\right)$ にて ローラコンパクタで転圧し，かつホイールトラッキング 試験機を用い， $45^{\circ} \mathrm{C}$ において約 1 時間トラバースをか け，ニィーディング作用を与えた試料ブロックを作製す る.

供試体はブロックからダイヤモンドカッタにより 4 $\times 4 \times 35 \mathrm{~cm}$ に切り出し，合成ゴムラテックスを塗付する ことにより供試体表面に薄いゴム被膜を形成せしめた 6 面カットの棒状供試体である.

\section{4. 動 的 性 状}

\section{（1）プログラム波による動的性状}

図一1に示したようにアスファルト層の変形係数が変 化すればアスファルト層下面に生ずる半径方向のひずみ $\left(\varepsilon_{r}\right)$ の分布は異なり，特に圧縮ひずみの最大值 $\left(\varepsilon_{C}\right)$ と 引張りひ皆みの最大值 $\left(\varepsilon_{T}\right)$ の比は 図一2 に示すよう に異なる. Bell Shape Wave を実験的にピンボードに よりプログラム波化するとき問題となるのは 図一1に 示したような Bell Shape Wave のどの波形を採用する かである. $\varepsilon_{C} / \varepsilon_{T}$ が $0.133 ， 0.267 ， 0.800$ である各波

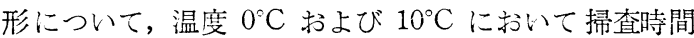

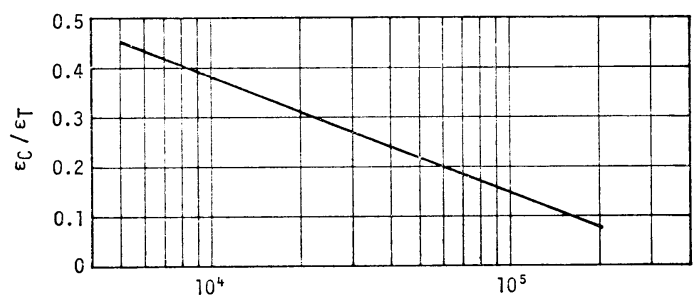

STIFFNESS OF ASPHALT LAYER, $E_{1}\left(\mathrm{Kg} / \mathrm{cm}^{2}\right)$

図一2 アスファルト層の変形係数とひずみ波形に おける圧縮ひずみの最大值 $\left(\boldsymbol{\varepsilon}_{C}\right)$ と引張ひ ずみの最大値 $\left(\varepsilon_{T}\right)$ の比との関係

表一3 プログラム波の波形によるスティフネス の值 $\left(\times 10^{4} \mathrm{~kg} / \mathrm{cm}^{2}\right)$

\begin{tabular}{c|ccc|ccc}
\hline Temperature & \multicolumn{3}{|c|}{$0^{\circ} \mathrm{C}$} & \multicolumn{3}{c}{$10^{\circ} \mathrm{C}$} \\
\hline Time $\varepsilon_{C} / \varepsilon_{T}$ & 0.133 & 0.267 & 0.800 & 0.133 & 0.267 & 0.800 \\
\hline $3.2 \times 10^{-2}$ & 3.8 & 4.3 & 4.3 & 3.4 & 3.6 & 4.0 \\
$8.5 \times 10^{-2}$ & 3.7 & 4.1 & 4.0 & 3.0 & 3.0 & 3.6 \\
$1.7 \times 10^{-1}$ & 3.5 & 4.0 & 3.8 & 2.7 & 2.8 & 2.9 \\
$3.4 \times 10^{-1}$ & 3.2 & 3.9 & 3.7 & 2.4 & 2.5 & 2.6 \\
$8.5 \times 10^{-1}$ & 3.0 & 3.6 & 3.5 & 2.0 & 2.0 & 2.0 \\
$1.7 \times 10^{\circ}$ & 2.6 & 3.4 & 3.0 & 1.6 & 1.6 & 1.6 \\
$3.4 \times 10^{\circ}$ & 2.4 & 3.1 & 2.7 & 1.3 & 1.3 & 1.3 \\
$8.5 \times 10^{\circ}$ & 2.1 & 2.8 & 2.4 & 0.96 & 0.96 & 0.96 \\
\hline & & & & & &
\end{tabular}

を変化させスティフネス（後述）を測定した結果を 表一 3 に示した.

波形によりスティフネスの值は若干異なるようである が明確にできるほどの差ならびに傾向を見い出せないこ とからここに示すような Bell Shape Wave における スティフネスは大きな変動を示さないと判断し, $\varepsilon_{C} / \varepsilon_{T}$ $=0.267$ すなわち $E_{1}=3.0 \times 10^{4} \mathrm{~kg} / \mathrm{cm}^{2}$ におけるひず み波形をもって Bell Shape Wave を代表させ実験を進 めた。

$\varepsilon_{C} / \varepsilon_{T}=0.267$ となるよう，またスムースカーブとな るようにピンボードにピンを打込むことによりプログラ 厶波（写真一1) を得る。温度 $-15 \sim 20^{\circ} \mathrm{C}$ において時 間軸 60 穴を掃查する時間を $0.2 \sim 50$ 秒と変化させ, 供試体中央部の下縁の引張りひずみの最大值（ $\varepsilon_{T}$ に相 当するひずみ）が $2.0 \times 10^{-4}$ となるように制御し，プロ グラム波を供試体に入力し，その応答として示される応 力波形（図一3）を得る。プログラム波によるスティフ ネスを 図一3に示したように最大応力（ $\sigma_{\max }$ ）と最大 ひずみ $\left(\varepsilon_{\max }\right)$ の比として定義し，載荷時間としてここ では一応かりに 図一3に示されている時間 $\left(t p^{*}\right)$ を採 用した。

図一4 は各温度におけるスティフネス-載荷時間曲線

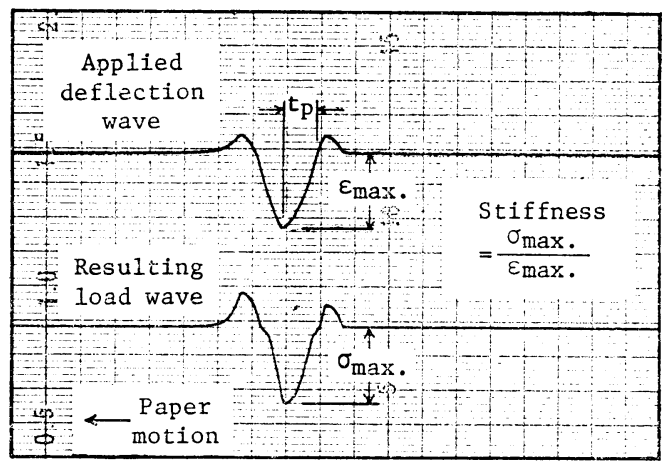

図一3プログラム波を入カとしたときの 動的応答

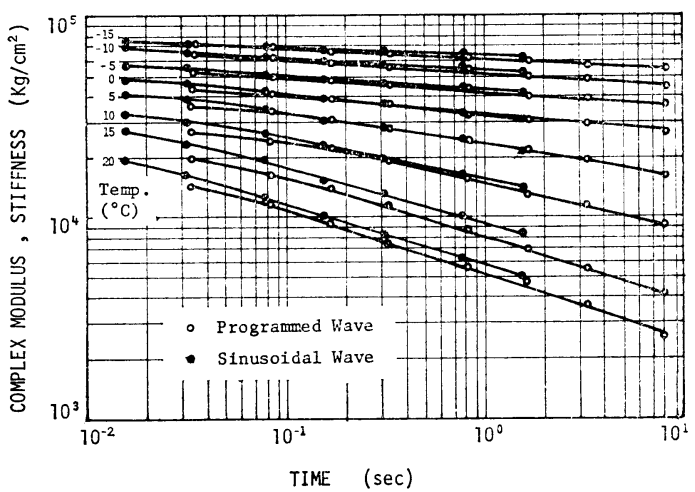

図-4 弾性率と載荷時間との関係 
を両対数紙上に示したものであり,これらは同一試験条 件において 6 本の供試体についての実験結果の平均值を 示したものである.なお各温度ならびに掃査時間におけ るスティフネスの変動係数は $0.07 \sim 0.16$ の範囲にあ り, 温度ならびに掃査時間の変化に対する変動係数の変 化の傾向は見られず, 变動係数の平均值は 0.10 を示 し,この種の材料の試験結果としては比較的良好なもの と考えてもよいであろう.

図に示した測定時間領域は舗装における表層の載荷時 間に換算（後に詳述）すれば，およそ時速 $35 \mathrm{~km}$ から $0.1 \mathrm{~km}$ の範囲にあり,この範囲内に打いてアスファル 卜混合物のスティフネスは温度の上昇および載荷時間が 長くなるにともない減少することがわかる.

\section{（2）正弦波による動的性状}

温度 $-15 \sim 20^{\circ} \mathrm{C}$ に打いて, 周波数 $(f)$ を $0.1 \sim$ $10 \mathrm{~Hz}$ と変化させ, 供試体中央部の上, 下縁のひずみの 最大值が $2.0 \times 10^{-4}$ となるように制御し, 正弦的に変化 するひずみ波形を供試体に入力し，その応答として示さ れる応力波形および位相角を得る方法 (強制振動非共振 法）で実験を行った．解析法などの詳細は筆者らの既発 表論文 ${ }^{10)}$ に示されているのでここでは省略する.

応力の振幅とひずみの振幅の比として示される複素弾 性率 $\left(\left|E^{*}\right|\right)$ と載荷時間 $(1 / \omega, \omega=2 \pi f)$ の関係を 図一 4 にプログラム波によるものと同時に示した.これらも 同一試験条件に㧍いて 6 本の供試体についての実験結果 の平均值を示したものであり, 各温度抢よび周波数にお ける複素弹性率の変動係数は $0.06 \sim 0.15$ の範囲にあ り,その平均值は 0.09 であり, プログラム波による場 合と大差はない. 前項と同じくこの実験領域は時速に換 算して $70 \mathrm{~km}$ から $0.7 \mathrm{~km}$ 程度である. なおこれらに ついてはさらに詳細に後述する.

\section{5. 疲労性状}

アスファルト混合物の疲労性状に関する研究の目的の 多くは正弦的に変化する応力またはひずみ波形を供試体 に与え，与えた応力またはひずみの大きさと破壊に至る までの繰り返し載荷回数（以下単に破壊回数とよぶ）と の関倸を求めることにあり, 多くの研究者によりかなり の成果を得ている. しかし前述したように車両走行にと もないアスファルト層に生ずるに生ずるひずみ波形は正 弦波ではないことから, Bell Shape Waveによる疲労 抵抗性を明らかにし，正弦波による場合との関連性を検 討することは実際のアスファルト埔装の寿命予測の観点 からも重要なこととなろら．この点に関する最近の研究 では van Dijk, W. らの研究 ${ }^{11}$ があり, 各種の手法を
用いてアスファルトならびにアスファルト混合物の疲労 性状を求めて抢り，その中で応力制御方式により Bell Shape Wave を供試体に与え実験を行い, 休止時間 (車 頭間隔, 車輪間隔に対応寸ると考えられる)によるアス ファルト混合物の疲労回復に注目し, 正弦波による場合 と比較し考察している.

筆者らは先に求めたプログラム波ならびに正弦波によ るひずみ制御方式の繰り返し載荷試験を行い，単位時間 当りの載荷回数が同一（1 秒間に 10 回）のとき, 波形 の差異が繰り返し載荷過程における動的性状の変化 ${ }^{4}$ な らびに破壊回数にいかなる影響を与えるかを，ここで論 じようとするものである.

温度 $-10,0,10^{\circ} \mathrm{C}$ において,プログラム波では 60 ピ ンを掃査する時間を 0.1 秒として最大引張りひずみを $(6.5 \sim 11.0) \times 10^{-4}$ と変化させ, 正弦波では周波数を $10 \mathrm{~Hz}$ としひずみ振幅を $(5.5 \sim 10.0) \times 10^{-4}$ と変化さ せ実験を行った。

\section{（1）動的性状の変化}

筆者らは先に繰り返し載荷によるアスファルト混合物 の力学的性状の変化を複素弾性率の低下率としてとらえ ることができることを指摘し，かつそれと破壊回数とは 密接な関係があることも明らかにした ${ }^{4}$.

ここでは, 繰り返し載荷過程に扔ける弾性率の変化を プログラム波の場合にはスティフネスの低下率として, また正弦波の場合には複素弾性率の低下率としてとら え，波形がこれら低下率にいかなる影響を与えるかを検 討した.

図一5 は与えるひずみを変化させた場合の両波形によ る低下率を示したものである。ある程度のばらつきを示 しながらも，ひずみと低下率との関係は両対数紙上でほ ぼ直線であり，同一ひずみを想定した場合各温度におい

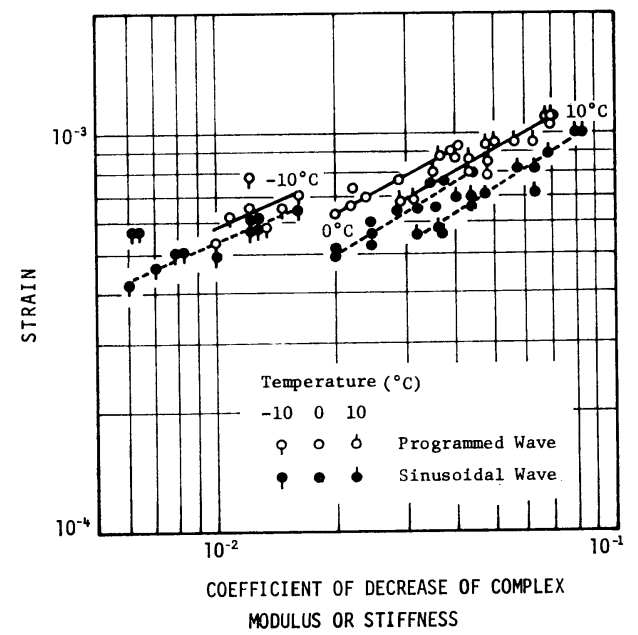

図一5ひずみと弾性率の低下率との関係 


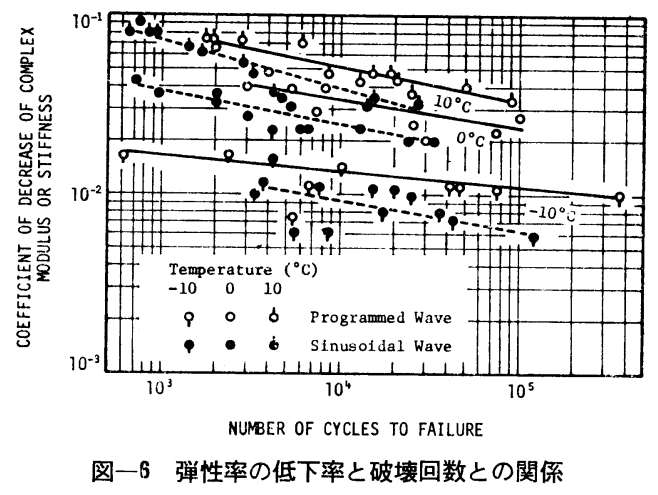

て正弦波に比しプログラム波で載荷したとき低下率は小 であることが明らかになった。

与えるひずみを変化させたときの低下率と破壊回数と の関係は 図一6 に示すように両対数紙でほぼ直線であ り, 各温度において低下率の減少とともに破壊回数は大 となる傾向を示している. 同一の低下率を想定した場 合, 各温度において正弦波に比しプログラム波で載荷し たとき破壊回数は大となることが明らかになった。

\section{(2) 破壊回数}

与えたひずみ量を $\varepsilon$, 破壊回数を $N$ とするとき，両 者の関係は両対数紙上で直線として示されることはすで に多くの研究者によって示されており, 両者の関係を示 寸実験式は以下のよりに示されることが多い。

$$
N=K \cdot\left(\frac{1}{\varepsilon}\right)^{\alpha}
$$

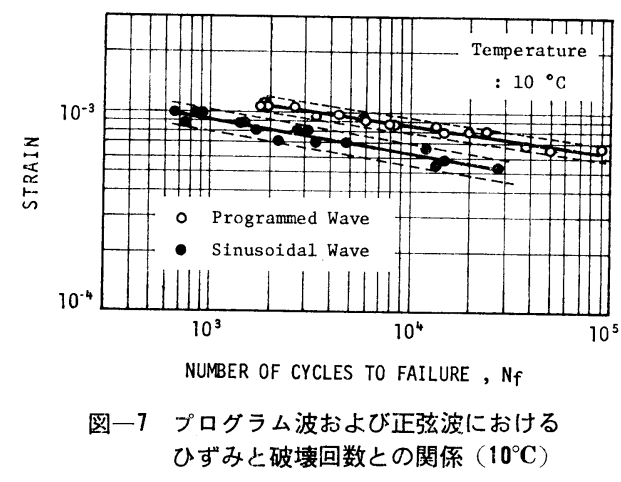

図一7 は例としてプログラム波执よび正弦波による温 度 $10^{\circ} \mathrm{C}$ に扔ける $\varepsilon-N$ 関係を示したものである.プロ グラム波扔よび正弦波による $\varepsilon-N$ 関係は，両波形とも ある幅をもった帯で示される。

また両波形による $\varepsilon-N$ 関係は波形により異なった所 に位置しており，図は同一ひずみを想定した場合，破壊 问数はプログラム波の場合大となることを示している.

各温度, 各波形における $\varepsilon \cdots N$ 関係に前記した実験式 を適用し，最小 2 乗法によりその倸数を算出し， $\varepsilon-N$ 関

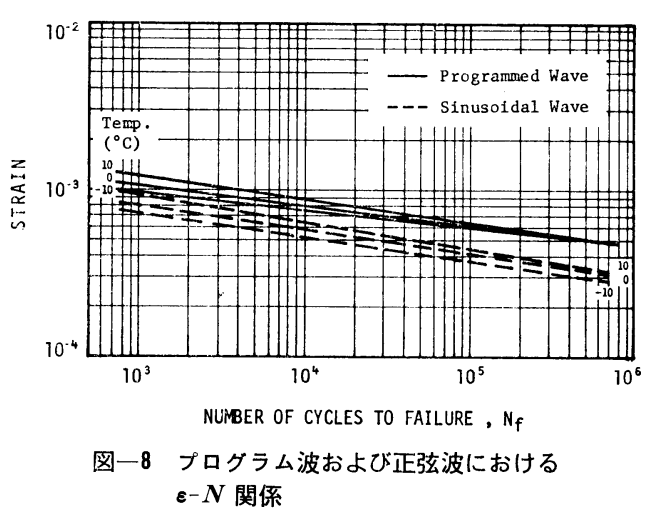

表-4 実 験式 の 係 数

\begin{tabular}{ccccc}
\hline \multicolumn{5}{c}{ Temperature $\left({ }^{\circ} \mathrm{C}\right)$} \\
\hline Sinusoidal & $K$ & $6.28 \times 10^{-17}$ & $1.03 \times 10^{-19}$ & $5.37 \times 10^{-24}$ \\
Wave & $\alpha$ & 6.329 & 7.092 & 9.009 \\
\hline Programmed & $K$ & $2.07 \times 10^{-18}$ & $2.40 \times 10^{-21}$ & $2.54 \times 10^{-28}$ \\
Wave & $\alpha$ & 7.092 & 7.937 & 10.092 \\
\hline$N_{f}=K \cdot\left(\frac{1}{\varepsilon}\right)^{\alpha}$ & & & & \\
\end{tabular}

係を求め図一8 に示した。 な打表一4には実験式の倸 数を一括して示している.

各温度に㧈いて正弦波による $\varepsilon-N$ 直線の傾きよりプ ログラム波によるそれの傾きの方が緩やかであり，雨波 形において温度の低下 とともに直線の傾きは 緩やかとなることも明 らかになった。

同一ひずみを与えた 場合, プログラム波お よび正弦波による破壊 回数にいかなる差異が あるかを明らかにする ために, 各温度に扔い 表一5 プログラム波による破壊 回数 $\left(\boldsymbol{N}_{f p}\right)$ と正弦波に よる 破壊回数 $\left(\boldsymbol{N}_{f s}\right)$ と の比

\begin{tabular}{c|rrr}
\hline \multirow{2}{*}{ Strain } & \multicolumn{3}{|c}{ Temperature $\left({ }^{\circ} \mathrm{C}\right)$} \\
& -10 & \multicolumn{1}{c|}{0} & 10 \\
\hline $10 \times 10^{-4}$ & 6.6 & 7.3 & 5.9 \\
$9 \times 10^{-4}$ & 8.0 & 8.1 & 6.1 \\
$8 \times 10^{-4}$ & 10.4 & 9.5 & 6.7 \\
$7 \times 10^{-4}$ & 13.5 & 10.8 & 7.7 \\
$6 \times 10^{-4}$ & 18.9 & 13.2 & 9.7 \\
$5 \times 10^{-4}$ & 24.6 & 14.1 & 9.6 \\
\hline
\end{tabular}

による破壊回数の比 $\left(N_{f p} / N_{f s}\right)$ を表一5 に示した.

表より与えるひずみが小さくなれば破壊回数の比は大 となる傾向を示し, その值は 24.6 にもなり, また温度 が低いほどその傾向も大となることが明らかにされた。

単位時間当りの載荷回数 (10 回/秒) ならびに最大引 張りひずみを同一とした繰り返し載荷試験に㧍いて，正 弦波に比しプログラム波を入力としたとき, アスファル 卜混合物の破壊回数が大となる現象はおおよそ以下の理 由によるものと推測されよう.

a）混合物に生ずる态力の大きさ 前章の動的性状に扔いて述べたように, $10 \mathrm{~Hz}$ の 
正弦波, 掃査時間 0.1 秒のプログラム波を入力と したときスティフネスの大きさは異なることから， 混合物に生ずる忍力の大きさはプログラム波の場合 の方が小さくなること.

b) ひび割れ発生の確率

正弦波を入力としたとき供試体に生ずるひずみ は，上縁および下縁において同じ大きさであること から，ひび割れは上縁または下縁のどちらかから入 るが，プログラム波の場合は下縁からしか入らない こと.

\section{c）休止時間の影響}

正弦波においては休止時間はゼロであるが，本研 究において用いたプログラム波には載荷 1 回当り約 0.018 秒の休止時間があり，この時間内に繰り返し 載荷によるダメージが回復すること.

\section{6. 動的性状の層構造問題への利用}

本章においては先に求めたアスファルト混合物の動的 性状の工学的な利用を目的とし, 室内実験で得られたア スファルト混合物の動的性状をアスファルト舗装構造に おける“層としての性状”としてとらえ，層構造の弾性 理論解法に適用することを試みた.

アスファルト混合物は周知のごとく粘弾性体であるこ とから，理論計算において弾性理論を適用することには 若干の疑問が生ずるが，第 3 回アスファルト舗装構造設 計に関する国際会議においても弾性理論も有力な 1 つの 手段であると評価されている ${ }^{12)}$. すなわち温度, 走行速 度などの環境条件を幅の狭い領域においてでも定量化す ることができるなら,その条件下において弾性理論を適 用することには問題はないと考えられる. 理論計算にお いては前述したように種々の仮定に基づいて計算が行わ れているのが現状であるが，一方環境条件の変化に対応 させ, 種々の因子を定量的に把握する努力が多くの研究 者により進められている.

路盤, 路床などに関する考察は本論丈の主旨からはず れることから，別の機会に譲ることにし，ここでは弾性 理論解法において非常に重要な因子の 1 つであるアスフ アルト層の変形係数についてのみ教察を進めることにす る.

前述したようにアスファルト混合物の弾性率は温度な らびに載荷時間の関数として示されることから，車両走 行時におけるアスファルト層の变形係数はその条件下に おける温度ならびに載荷時間を求めることができれば決 定することができ, 温度に関しては近似的に前述した温 度の異なる（すなわち変形係数の異なる）層の積重ねと いう考え方で処理することができる.

\section{（1）アスファルト層において採用すべき載荷時間}

車両走行に基づくアスファルト層において採用すべき 載荷時間に関する研究については, Klomp, A.J.G. ${ }^{13)}$, Hofstra, A. ${ }^{3)}$, Barksdale, R.D. ${ }^{14)}$ らのものがあるが, そのいずれもアスファルト層に生ずるひずみまたは応力 波形に着目し，その波形の中に載荷時間を定義すること を試みている. 研究者によって取り上げる波形も異なり 載荷時間の定義も異なっていることから，どの手法が最 も合理的であるかの判断は非常に困難であると思われ る.

本研究ではアスファルト層下面に生ずる半径方向のひ ずみ $\left(\varepsilon_{r}\right)$ 波形によるスティフネスと正弦波による複素 弾性率を走行速度を考慮に入れて比較し，同一温度にお いて弾性率を等值とする載荷時間を見い出し，それをア スファルト層の載荷時間とすることを試みている.

4.において，プログラム波による場合と正弦波によ る場合のアスファルト混合物の弾性率と載荷時間の関係 を，温度をパラメーターとして示した（図一4）。

両波形における弾性率一時間曲線は各温度においてほ ぼ相似形であることから，プログラム波による弾性率時間曲線を時間軸に沿って平行移動させ，正弦波による 弾性率-時間曲線に重ね合わせてみた。その結果, 本研 究の温度範囲 $\left(-15 \sim 20^{\circ} \mathrm{C}\right)$ における各温度において, 闰者の弾性率一時間曲線は良い重なりを示すことが明ら かとなった.

この手法は,アスファルト混合物の弾性率は温度と時 間の関数として示されることから，温度を同一としたと き時間のみの関数となり, 弾性率が等值であるならばそ のときの載荷時間は当然等值であるとの考え方に基づい ている.このことからプログラム波による弾性率-時間曲 線と正弦波による曲線とを一致させるための移程量を求 めることにより，プログラム波の載荷時間を決定するこ とができる. 寸なおち正弦波における載荷時間 $t_{s}\left(t_{s}=\right.$ $1 / \omega, \omega$ : 角速度）とプログラム波における載荷時間 $t_{p}$ (前出) との間には以下に示すような関係があることが 明らかになった。

$$
\begin{aligned}
\log t_{s} & =\log t_{p}+0.16 \\
t_{s} & \fallingdotseq 1.5 t_{p}
\end{aligned}
$$

車㟧走行に伴う舗装体のアスファルト層における載荷 時間は,アスファルト層下面に生ずる半径方向のひずみ 波形に拈いて，圧縮から引張に変わる点から引張ひずみ の最大値になる時間, $t_{p}$, に 1.5 を乗じた時間となる.

\section{（2）アスファルト層の変形係数}

層構造の弾性理論解法を用いて, 図一1 に示した 3 層 の舗装構造を例として取りあげ, アスファルト層の変形 
係数を求めることを試みた.

正弦波を用いて測定したアスファルト混合物の複素弾 性率-時間曲線（図一4）に時間・温度換算則を適用し， 基準温度 $\left(T_{0}\right)$ を $10^{\circ} \mathrm{C}$ としたときの複素弾性率のマス ターカーブを求める. そのときの移程量 $\left(\log a_{T}\right)$ と温 度の関係は付表に示されている. また各温度を基準とし て複素弾性率のマスターカーブ群（付図）を描く.なお 付図には测定領域よりも高温 $\left(25 \sim 40^{\circ} \mathrm{C}\right)$ におけるもの も示されているが，その算出方法の詳細については付録 に述べてある.

一方これらの複素弾性率のマスターカーブ群のかわり に, 定ひずみ速度試験から得られる線型粘弾性領域内の スティフネスからそれらを求めることもできる.

図一9 はアスファルト混合物の複素弾性率のマスター カーブ群の一部, および層構造の弾性理論解法を用いて 算出したアスファルト層の載荷時間（前出）とアスファ ルト層の 変形係数との 関係を示したものである. 図一9 を得るための具体的な手順は付録に示してある.

なお 図一9においては, 便のため縦軸に載荷時間, 横 軸に弾性率 (変形係数) を示してある.またアスファル ト混合物の弾性率は, 舗装が遭遇するような環境条件下 （温度としては最低気温から最高気温 + 約 $30^{\circ} \mathrm{C}$, 載荷時

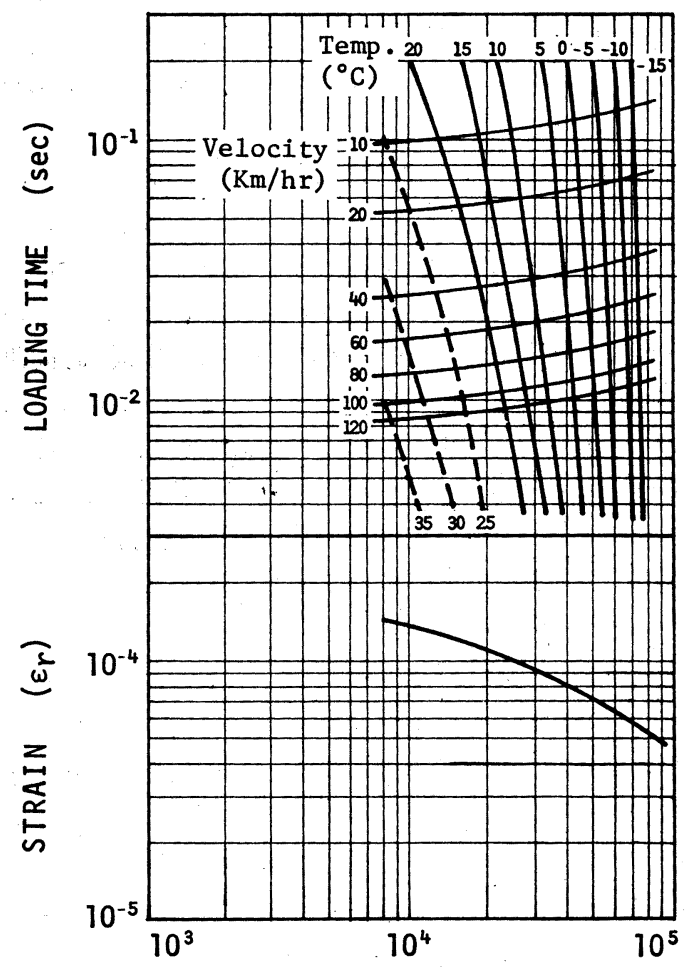

STIFFNESS OF ASPHALT LAYER, $E_{1}\left(\mathrm{Kg} / \mathrm{cm}^{2}\right)$

図一9 アスファルト届の変形保数と諓荷時間および 半径方向の引張ひずみとの関係
間としては $10^{-3}$ 秒から数日) で求められなければなら ないかもしれないが, アスファルト層の変形倸数が路盤 の変形係数を下まわる（変形係数の逆転）のような場合 については除外することとする．このことからここでは W.F.L. 式（付録 参照）を利用し，温度 $25 \sim 35^{\circ} \mathrm{C}$ にお ける マスターカーブをも示しているが, 変形係数 8.25 $\times 10^{3} \mathrm{~kg} / \mathrm{cm}^{2}$ 以下の值は除いてある.

図一9より，車両走行速度をパラメーターとしたアス ファルト層の載荷時間と変形係数との関係を示した曲線 と複素弾性率のマスターカーブ群との交点が, 各温度お よび各車両走行速度に対応したアスファルト層の変形係 数 $\left(E_{1}\right)$ を与える座標点となる. またこれら各交点にお ける時間は，車両走行に基づいてアスファルト層に生ず る正弦波に対応した載荷時間であると同時に，ある温度 におけるアスファルト層の変形係数を与える載荷時間と なる.

図一9 には車両走行速度を $10 \sim 120 \mathrm{~km} / \mathrm{hr}$ にとった ときのアスファルト層の載荷時間と $E_{1}$ との関係をも示 してあり, アスファルト層下面に生ずる半径方向の最大 引張ひずみと $E_{1}$ との関係も同時に示してある.

アスファルト層の変形係数, 載荷時間, ひずみについ て，図一9より以下に示すような 事項が明らかにされ た.

a）車両走行にともないアスファルト層に生ずる載荷 時間は，3 層構造において車速 $10 \sim 100 \mathrm{~km} / \mathrm{hr}$ に 対して $0.1 \sim 0.01$ 秒すなわち $10^{-2}$ 秒のオーダーで ある・

b） アスファルト層の変形係数が大となるほど，すな わち温度が低下するほど, 車両走行速度が一定であ ってもアスファルト層における載荷時間は長くなる 傾向を示す.

c) 舗装体の温度 $-15 \sim 35^{\circ} \mathrm{C}$ において, 輪荷重 $5 \mathrm{t}$ の車両が走行するときのアスファルト層の変形係数 $\left(E_{1}\right)$ ならびにアスファルト層下面に生ずる半径方 向の最大引張ひずみ $\left(\varepsilon_{r}\right)$ は, 温度および走行速度 によりかなり異なっている.このことをより明らか

\section{表一6 アスファルト届の変形保数および} 半徍方向の引張ひずみ

\begin{tabular}{c|c|ccccc}
\hline \multirow{2}{*}{$\begin{array}{c}\text { Velocity } \\
(\mathrm{km} / \mathrm{hr})\end{array}$} & & \multicolumn{5}{|c}{ Temperature $\left({ }^{\circ} \mathrm{C}\right)$} \\
\hline \multirow{2}{*}{10} & 35 & 25 & 10 & 0 & -15 \\
\hline \multirow{2}{*}{60} & $E_{1}^{*}$ & & 0.81 & 2.4 & 4.2 & 7.0 \\
& $\varepsilon_{r}^{* *}$ & & 13.5 & 10.0 & 7.8 & 5.8 \\
\hline \multirow{2}{*}{120} & $E_{1}$ & & 1.3 & 3.1 & 4.9 & 7.2 \\
& $\varepsilon_{r}$ & & 12.0 & 9.0 & 7.2 & 5.6 \\
\hline & $E_{1}$ & 0.85 & 1.6 & 3.3 & 5.1 & 7.4 \\
& $\varepsilon_{r}$ & 13.2 & 11.5 & 8.8 & 7.0 & 5.4 \\
\hline
\end{tabular}

* $E_{1} \times 10^{4}\left(\mathrm{~kg} / \mathrm{cm}^{2}\right) \quad{ }^{* *} \varepsilon_{r} \times 10^{-5}$ 
にするために, 温度 $-15 \sim 35^{\circ} \mathrm{C}$, 走行速度 $10 \sim$ $120 \mathrm{~km} / \mathrm{hr}$ における $E_{1}$ ならびに $\varepsilon_{r}$ の值を表一6 に示した.

表は, 温度 $25^{\circ} \mathrm{C}$ において走行速度が $120 \mathrm{~km} / \mathrm{hr}$ から $10 \mathrm{~km} / \mathrm{hr}$ に低下すれば最大引張ひずみは 1.17 倍となり，また走行速度 $60 \mathrm{~km} / \mathrm{hr}$ においては温度 が $-15^{\circ} \mathrm{C}$ から $25^{\circ} \mathrm{C}$ に上昇すればそれは 2.14 倍 にもなることを示している.また $-15^{\circ} \mathrm{C}, 120 \mathrm{~km} /$ $\mathrm{hr}$ の場合と $25^{\circ} \mathrm{C}, 10 \mathrm{~km} / \mathrm{hr}$ の場合とでは後者の 最大引張ひずみは前者の 2.5 倍ともなる.

以上のことより，車両走行にともないアスファル ト層に生ずる引張ひずみを算出するときには，重要 な入力データであるアスファルト層の変形係数が温 度ならびに車両走行速度に大きく依存することか ら，温度ならびに車両速度を無視することができな い.

\section{7. 結論}

本研究において明らかにされた事項を要約すればおお よそ次の通りである.

（1） 3 層構造の弾性理論解法を用いてアスファルト 層下面における半径方向のひずみ分布を算出し，その波 形をアスファルト混合物に入力し動的性状を求める一 方, 通常この種の研究に用いられている正弦波に上る動 的性状をも求め, 両者の差異を明らかにした。

（2）アスファルト混合物の疲労破壊回数はアスファ ルト層としての荷重分散性能を保持する限界であるとの 観点から, 車両走行にともないアスファルト層下面に生 ずるひずみ波形および正弦波により疲労試験を行い，繰 り返し載荷過程における弾性率 (Stiffness Modulus)の 変化を明らかにするとともに，両者の波形による疲労性 状の差異を明らかにし，かつ関連づけを行った．すなわ ち 正弦波に比し疲労破壊回数は約 $6.0 \sim 24.6$ 倍にもな ることを明らかにした。

(3) 同一温度において弾性率が等值であるならばそ のとき採るべき載荷時間も等值であるとの観点から，ア スファルト層における載荷時間の定義を試み，それはア スファルト層下面に生ずる半径方向のひずみ波形におい て圧縮から引張に変わる点から引張ひずみの最大值にな る時間 $\left(t_{p}\right)$ に 1.5 を乗じた時間となることを明らか にした.

（4）車両走行にともないアスファルト層下面に生ず る引張ひずみを算出する際, 重要な入力データとなるア スファルト層の変形係数の温度ならびに載荷時間依存性 を明らかにし, 舗装体の温度が既知のとき, 車両走行速
度に対応した載荷時間を求め, 最大引張ひずみの值を算 出する手法を提案した。

筆者らは先に, アスファルト混合物への粘弹性論の適 用の可否について，また実際の道路舗装において生ずる であろら載荷時間, 温度, ひずみ領域においてアスファ ルト混合物の動的応答について論じ,さらに繰り返し載 荷時の動的応答の変化について考察を加え, アスファル 卜混合物の動的性状について一連の研究を進めてきた.

本論文はそれらの研究成果を基礎として, アスファル 卜混合物の動的性状ならびに疲労性状を車両走行にとも ないアスファルト層に生ずるひずみ波形で論じ，層構造 における理論解法に扔いて最む重要な入力データであ るアスファルト層の変形係数を合理的に決定する方法を 提案した.このことから, 理論解法が今まで単に理論と して発展してきたものを, 車両走行速度をも考慮に入れ た材料物性がより明らかにされ理論に組入れられるなら ば，舖装の理論設計の実用への適用がより実際的なもの となる. なお本研究において用いた舗装構造の力学的解 については本学芳村 仁教授のご指導をいただき, 牛尾 俊介, 鈴木征勝, 森吉昭博らの諸氏により作成されたプ ログラムを用いた。ここに関係各位に感謝の意を表する 次第である. また数值計算には北海道大学大型計算機セ ンターの FACOM 230-75 を使用した.

なお本研究は文部省科学研究費の交付を受けて実施し たものである.

\section{付 録}

\section{（1）複素弾性率のマスターカーブおよび算出法}

時間・温度換算則の原理からして，マスターカーブの 形は温度によらず同一であるが，図上においてその位置 するところは異なる。したがって,ある基準温度における マスターカーブおよび温度とシフトファクター $\left(\log a_{T}\right)$ の関係の 2 者から, 温度ならびに載荷時間が変化したと きの複素弾性率を求めることができる.しかし計算等の 手段が入るため実用には不便であることから, 実用に供 するため各温度におけるマスターカーブを描き,また W.L.F. 式を利用し, 測定温度領域よりも高温 (25 $40^{\circ} \mathrm{C}$ ) におけるものも付図に示した.

アスファルト混合物はほぼ熱レオロジー的に単純な物 質として取扱らことのできるものであることは，筆者ら はすでに明らかにしている.たとえば温度をパラメータ 一としてアスファルト混合物の複素弾性率-時間曲線を 表わすことができ, ある温度を基準温度 $\left(T_{0}\right)$ とし他の 温度における曲線を $T$ 。における曲線にまで平行移動さ 


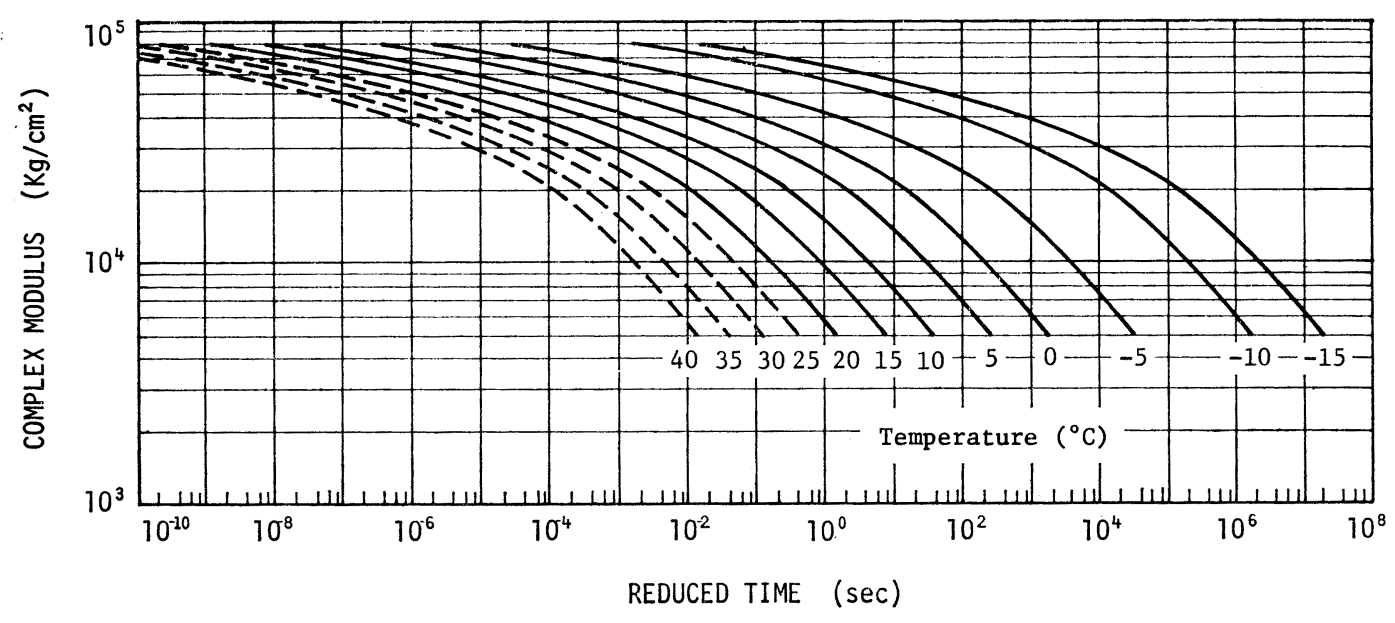

付図 複素弾性率のマスターカーブ群

\begin{tabular}{r|c|c}
\multicolumn{2}{c}{ 付表 シフトファクター } \\
\hline $\begin{array}{c}\text { Temp. } \\
\left({ }^{\circ} \mathrm{C}\right)\end{array}$ & $\log a_{T}$ & $\begin{array}{c}\log a_{T} \\
\text { from } T_{s}\end{array}$ \\
\hline-15 & 5.70 & 5.94 \\
-10 & 4.65 & 4.32 \\
-5 & 2.94 & 2.97 \\
0 & 1.72 & 1.83 \\
5 & 0.85 & 0.85 \\
10 & 0 & 0 \\
15 & -0.76 & -0.74 \\
20 & -1.42 & -1.40 \\
25 & - & -1.99 \\
30 & - & -2.51 \\
35 & - & -2.98 \\
40 & - & -3.41 \\
\hline
\end{tabular}
選択し用いるならば，すべての物質のシフトファクター の温度依存性が次式に示す一般式によってよく表わされ ることを明らかにした

$$
\begin{aligned}
\log a_{T} & =-c_{1}\left(T-T_{s}\right) /\left(c_{2}+T-T_{s}\right) \\
c_{1} & =8.86 \\
c_{2} & =101.6
\end{aligned}
$$

この関係は固体高分子に限らず, 高分子溶液, ガラス 形成能をもつ有機低分子化合物および無機ガラスなどに ついて, 極めて広い温度領域, すなわちガラス転移温度 $T_{g}$ からその $100^{\circ} \mathrm{C}$ 高温まで成立するとされている.

系に固有な標準温度 $T_{s}$ 以外の 任意の温度 $T_{0}$ を基 準とすれば上式は以下のように表わすことができるとさ れている16).

$\log a_{T}=-c_{1} c_{2}\left(T-T_{0}\right) /\left(c_{2}+T-T_{s}\right)\left(c_{2}+T_{0}-T_{s}\right)$

アスファルト混合物についてもこれらの関係が成立す るとして, 付表に示した温度と $\log a_{T}$ の関係から標準 温度 $T_{s}$ を求めた結果, $T_{s}=36.3^{\circ} \mathrm{C}$ なる值を得た。 ま たここで得られた $T_{s}$ を用いて, 各温度における $\log a_{T}$ を算出し，その結果を付表に同時に示した．表を見る に，両者のシフトファクター $\left(\log a_{T}\right)$ はかなり良い一
致を示している.このことから, 詳練な議論はあるにし ても, 標準温度 $\left(T_{s}\right)$ を求めることにより, 測定温度領 域外の温度を含む任意温度におけるマスターカーブを描 くことができるものと思われる.

\section{（2）アスファルト層の変形係数の決定法}

アスファルト層における載荷時間ならびに変形係数を 求めるための手順は以下に示す通りである.

a）複素弾性率のマスターカーブ群（付図）を用意す る.

b) ある温度においてアスファルト層の変形係数 $\left(E_{1}\right)$ を仮定し, 層構造の弹性理論解法によりアス ファルト層下面の半径方向ひずみ $\left(\varepsilon_{r}\right)$ と載荷面中 心からの距離との関係すなわちひずみ分布を求め る.

c）載荷面の中心からひずみがゼロとなる点までの距 離 $(L)$ を求め, 車両走行速度 $(V)$ との商として 時間 $\left(t_{p}=L / V\right)$ を計算する.

d) 時間 $t_{p}$ に先に求めた係数 1.5 を乗じてアスファ ルト層における載荷時間 $t$ を求める.

e）この載荷時間 $t$ の值と b) において仮定した $E_{1}$ の值の座標点を a）において用意した図上にプロッ トする.

f） $E_{1}$ の值を変化させ b)〜e）の手順を繰り返し多 くの座標点を求め, そ机らを結んで $E_{1}$ と $t$ との 関係を示す曲線を得る.

g) $E_{1}-t$ 曲線とマスターカーブ群との交点が各温度 に抬けるアスファルト層の変形係数 $E_{1}$ を与える座 標点となる. また交点における時間は, 車両走行に 基づいてアスファルト層に生ずる正弦波に対応した 載荷時間であると同時にある温度におけるアスファ ルト層の変形係数を与える時間となる. 


\section{参 考 文 献}

1) Heukelom, W. and Klomp, A.J.G. : Dynamic testing as a means of controlling pavements during and after construction, 1st Int. Nat. Conf. on the structural design of asphalt pavements, Michigan, 1962.

2）笠原 篤・上岛 壮・菅原 照雄: 共振法によるアスフォ ルトおよびアスファルト混合物の動的粘弾性, 土木学会 論文報告集，第 208 号， 1972.

3) Hofstra, A. and Valkering, C.P. : Comparison of laboratory measurements under simulated traffic conditions with theory, 3rd Int. Nat. Conf. on the Structural Design of Asphalt pavements, Vol. 1, 1972. その他多数

4）笠原 篤・菅原照焳：繰返し載荷過程におけるアスファル 卜混合物の動的性状の 変化について, 土木学会論文報告 集, 第 235 号, 1975 .

5) Burmister, D.M. : The theory of stresses and displacements in layered system and applications to the design of airport runways, Proc. 23rd-Annual Meating of H.R.B., Vol. 23, 1943.

6) Schiffmann, R.L. : General analysis of stresses and displacements in layered systems, 1st Int. Nat. Conf. on the structural design of asphalt pavements, 1962 .

7) Yoshimura, J., Ushio, S. and Sugawara, T. : Stressesin multi layered systems, Memoirs of the Faculty of Engineering, Hokkaido University, Vol. 13, No. 2,1972 .
8) Baker, R.F. : A structural design procedure for pavements, 1st Int. Nat. Conf. on the structural design of asphalt pavements, 1962.

9) Heukelom, W. and Foster, C.R. : Dynamic testing of pavements, Proc. of the A.S.C.E., SM 1, 1960.

10）笠原 篤・菅原照雄 : アスフォルト混合物の動的応答に関 する研究, 土木学会諭文報告集, 第 215 号, 1973.

11) van Dijk, W., Moreaud, H., Quedeville, A. and Uge, P. : The fatigue of bitumen and bituminous mixes, 3rd Int. Nat. Conf. on the structural design of asphalt pavements, 1972.

12) Proc. of 3rd International Conference on the Structural Design of Asphalt Pavements, Vol. 2, 1972.

13) Klomp, A.J.G. and Niesman, Th.W. : Observed and calculated strains at various depths in asphalt pavements, 2nd Int. Nat. Conf. on the structural design of asphalt pavements, 1967.

14) Barksdale, R.D. : Compressive stress pulse time in flexible pavements for use in dynamic testing, H.R. R., No. 345, Highway Soils Engineering 11 reports, 1971.

15) Williams, M.L., Landel, R.F. and Ferry, J.D. : The temperature dependence of relaxation mechanisms in amorphous polymers and other glass-forming liquids. J. Am. Chem., Sos., 1955.

16）小野木重治：レオロジー要論, 槇書店, 1957.

(1976.3.26 · 受付) 